\title{
The impacts of climate change on irrigation and crop production in Northeast China and implications for energy use and GHG Emission
}

\author{
Tingting Yan ${ }^{1}$, Jinxia Wang ${ }^{2}$, Jikun Huang ${ }^{2}$, Wei Xie ${ }^{2}$, and Tingju Zhu ${ }^{3}$ \\ ${ }^{1}$ Development Research Center of the Ministry of Water Resources, Beijing 100038, China \\ ${ }^{2}$ School of Advanced Agricultural Sciences, Peking University, Beijing 100871, China \\ ${ }^{3}$ International Food Policy Research Institute, 2033 K St, NW, Washington, DC 20006, USA
}

Correspondence: Jinxia Wang (jxwang.ccap@pku.edu.cn)

Received: 31 December 2017 - Revised: 26 March 2018 - Accepted: 26 March 2018 - Published: 5 June 2018

\begin{abstract}
The water-food-energy-GHG nexus under climate change has been gaining increasing attention from both the research and policy communities, especially over the past several years. However, most existing nexus studies are qualitative and explorative in nature. So far, very few studies provide integrated analysis of this nexus across all the four sectors. The purpose of this paper is to examine this nexus by assessing the effects of climate change on agricultural production through the change in water availability, evaluating the adjustment responses and resulting energy consumption and GHG emission, with the Northeast China as a case study. Based on our simulation results, by 2030 , climate change is projected to increase water supply and demand gap for irrigation in Northeast China. Due to the increase in water scarcity, irrigated areas will decrease, and the cropping pattern will be adjusted by increasing maize sown areas and decreasing rice sown areas. As a result, the total output of crops and profits will clearly be reduced. Finally, energy consumption and GHG emission from irrigation will be reduced. This study suggests that climate change impact assessment fully consider the nexus among water, food, energy and GHG; however, more studies need to be conducted in the future.
\end{abstract}

\section{Introduction}

Increasing evidence of climate change intensifies our concern about its impacts on agricultural production and water availability. With high confidence, IPCC (2014) concluded that global temperature will continue to increase in the future. Numerous agronomic and economic studies found that agricultural production is vulnerable to climate change; and its vulnerability is highly related to adaptation capacity (Mendelsohn and Dinar, 2009; IPCC, 2014). Besides direct impact on crop productivity, climate change also indirectly influences agricultural production through water availability changes. Recent studies reveal that climate change may enlarge the gap between irrigation demand and supply, therefore jeopardizing irrigated agriculture (Rosenzweig et al., 2004; Wang et al., 2013). Obviously, to understand the impacts of climate change on agricultural production requires integrated analysis that combines climate change impacts on both the agricultural and water sectors. In addition, farmers' adaptive responses in adjusting agricultural production also need to be included into the impact assessment (Wang et al., 2013). However, so far very few such integrated analyses have been conducted for China.

Importantly, the change of water availability and agricultural production will also influence energy consumption and GHG emission. Theoretically, water, food, energy and GHG form a complex web of interlinked components, which is more complicated under the background of climate change. Food production highly depends on irrigation; irrigation water supply consumes energy in pumping, delivering water, or other activities. Finally, energy production results in GHG emission, which indirectly influence agricultural production and irrigation through climate change feedbacks. In 2011, the Water-Energy-Food Security Nexus Conference held in Bonn, Germany, which started using the nexus terminology for the first time and concluded that the issues of water, food 
and energy security are highly related, and thus must be addressed with a comprehensive insight and a multidisciplinary approach into the nexus (Waughray, 2011). Since then, the water-food-energy-GHG nexus under climate change has become a hot topic.

However, most of those published literatures focused on the two-way relationships, such as Food-Energy Nexus (Wise et al., 2014; Cobuloglu and Büyüktahtakın, 2015), Energy-Water Nexus (Wang et al., 2012; Kao et al., 2015) or Food-Water Nexus (Waughray, 2011; Wang et al., 2013), little research analysed the relationship among water, energy and food as a whole. According to Keairns et al. (2016), as of December 2016, there were only about 40 literatures, whose subject and abstract contain water, energy, food and nexus at the same time. Interestingly, although not only the concept of the water-energy-food nexus and its important role on decision-making under climate change but also the systematic approach to the nexus have been increasingly addressed by many scholars (Bazilian et al., 2011; Martin-Gorriz et al., 2014; Rasul and Sharma, 2015), little study has quantified the water-food-energy nexus for the future. Even in few work with estimation of future water-food-energy nexus (Nelson et al., 2009; Finley and Seiber, 2014), climate change scenarios published by IPCC (Van Vuuren et al., 2011a) are not used.

Therefore, to have a better understanding of the water, food, energy and GHG nexus with forthcoming climate change, we must answer the following questions. How will climate change affect water availability for agricultural production? If water availability changes, then, what types of adjustments in agricultural production will likely to be made by farmers? That is, what changes will be made in irrigated and rain-fed areas? How will cropping patterns be adjusted? Based on these adjustments, how will farmers' profits from agricultural production change? Due to changes in water availability and the adjustments in agricultural production, how will energy consumption and GHG emission be influenced?

As a major grain production region in China, the Northeast depends to a large extent on irrigation for crop production. The region encompasses four provinces (Liaoning, Jilin, Heilongjiang and the northeastern part of Inner Mongolia) and covers two large river basins (Songhuajiang and Liaohe River Basins, SRB and LRB). In China, $41 \%$ of soybean, $34 \%$ of maize and $40 \%$ of japonica rice are produced in the Northeast (NBSC, 2013). About $30 \%$ of the grain produced in this region depends on irrigation. According to national and regional plans, to further increase agricultural production in Northeast China requires further expansion of irrigated areas. However, the water endowment in this region is limited and it tends to decrease. Per capita water availability is $1500 \mathrm{~m}^{3}$ in the region, lower than the national average $\left(2100 \mathrm{~m}^{3}\right.$ per capita). In the LRB, per capita water availability is only approximately $630 \mathrm{~m}^{3}$ (NBSC, 2013). Over the past 50 years (1961-2011), runoff in the SRB and LRB has declined by 3 and $8 \%$, respectively (ECSNCCA, 2011). In the future, water is expected to become more scare in these two river basins (Wang et al., 2013).

The overall goal of this study is to illuminate the waterfood-energy-GHG nexus under climate change in Northeast China by assessing the effects of climate change on agricultural production through the change in water availability, evaluating the adjustment responses by farmers and resulted changes in energy consumption and GHG emission. We first simulate the impacts of climate change on crop yield through its effects on the water availability without considering farmers' adaptive adjustments. Second, after considering farmers' autonomous adaptations to climate change driven by profit maximization (and risk minimization), we analyse changes in cropping pattern, irrigation intensity, crop yield and output, and profits. Finally, the energy consumption and GHG emission from irrigation are estimated at both the regional and the national levels.

\section{Methodology and data}

It takes process to estimate the effects of climate change on irrigation water supply and agricultural production, energy consumption and GHG emission. First, we introduce the China Water Simulation Model (CWSM) that is used to simulate the impacts of climate change on water and agricultural production. Second, we describe the steps and methods to estimate the energy consumption and GHG emission due to the changed water and agricultural production. Finally, we clarify the specifications of three simulation scenarios, including a reference scenario and two climate change scenarios.

\subsection{Specification of the China Water Simulation Model}

The model used in this study is the CWSM model developed by the first and second authors, together with their team. The CWSM is a model that integrates climate, hydrology, crop and water allocation optimization to simulate the regional water balance, water allocation and their impacts on agricultural production under socioeconomic, policy, and climate change scenarios (Wang et al., 2013). The model includes two main components: the water balance and the water allocation. When the balance between the water supply and water demand is affected by climate change, water is reallocated among sectors (i.e. agricultural, industrial and domestic water users) and within the agricultural sector. For a detailed description of the CWSM, see Wang et al. (2013). In this paper, an improvement is made for allocation within the agricultural sector.

The major approach used in the water allocation within the agricultural sector in the CWSM is the Positive Mathematical Programming (PMP) model (Wang et al., 2013). The PMP model is a method for calibrating models of agricultural production with resource constraints by using nonlinear production or cost functions, avoiding the corner solution in a linear optimization model. The method is implemented in 
three stages. First, calibration constraints are added to the primal problem. Second, the shadow values from the first step are used to estimate the parameters of a new cost function. Third, a non-linear objective function is specified, without the calibration constraints such that it can reproduce the baseyear activity levels, closely or exactly, thus verifying the calibrated unconstrained optimization model.

Based on the work of Wang et al. (2013), our model has made the following major improvements. First, a production function with a constant elasticity of substitution (CES) is used, considering the substitution between irrigated land and irrigation water, the return-to-scale effect, and the relationship between crop yield and irrigation water. Second, the shadow costs of the inputs are introduced into the cost function, which are calibrated by using the method specified by Graveline and Mérel (2014). More details about parameters specification can be found in Yan (2015). Compared with our previous study (Wang et al., 2013), the CES PMP model used in this paper is more flexible, ensuring realistic responses to price changes, replicating the observed profits and taking into account yield response to irrigation water.

The model is given as follows for the SRB and LRB.

$$
\begin{aligned}
& \left\{\begin{array}{l}
\operatorname{Max}_{\mathrm{r}, \mathrm{c}, \mathrm{ir}} \\
A_{\mathrm{r}, \mathrm{c}, \mathrm{rf}} \\
W_{\mathrm{r}, \mathrm{c}, \mathrm{ir}}
\end{array} \prod_{\mathrm{r}}=\sum_{\mathrm{c}}\left[P_{\mathrm{r}, \mathrm{c}}\left(Q_{\mathrm{r}, \mathrm{c}, \mathrm{ir}}+Q_{\mathrm{r}, \mathrm{c}, \mathrm{rf}}\right)\right.\right. \\
& -\left(C_{\mathrm{r}, \mathrm{c}, \mathrm{a}}+\mu_{\mathrm{r}, \mathrm{c}, \mathrm{a}, \mathrm{ir}}\right) A_{\mathrm{r}, \mathrm{c}, \mathrm{ir}} \\
& \text { - }\left(C_{\mathrm{r}, \mathrm{c}, \mathrm{a}}+\mu_{\mathrm{r}, \mathrm{c}, \mathrm{a}, \mathrm{rf}}\right) A_{\mathrm{r}, \mathrm{c}, \mathrm{rf}} \\
& \left.-\left(C_{\mathrm{r}, \mathrm{c}, \mathrm{w}}+\mu_{\mathrm{r}, \mathrm{c}, \mathrm{w}}\right) W_{\mathrm{r}, \mathrm{c}, \mathrm{ir}}\right] \\
& \text { st. }\left\{\begin{array}{l}
\sum_{\mathrm{c}}\left(A_{\mathrm{r}, \mathrm{c}, \mathrm{ir}}+A_{\mathrm{r}, \mathrm{c}, \mathrm{rf}}\right) \leq \sum_{\mathrm{c}}\left(\bar{A}_{\mathrm{r}, \mathrm{c}, \mathrm{ir}}+\bar{A}_{\mathrm{r}, \mathrm{c}, \mathrm{rf}}\right) \\
\sum_{\mathrm{c}} W_{\mathrm{r}, \mathrm{c}, \mathrm{ir}} \leq I_{\mathrm{cc}} \\
Q_{\mathrm{r}, \mathrm{c}, \mathrm{ir}}=\alpha_{\mathrm{r}, \mathrm{c}, \mathrm{ir}}\left(\beta_{\mathrm{r}, \mathrm{c}, \mathrm{ir}, \mathrm{a}} A_{\mathrm{r}, \mathrm{c}, \mathrm{ir}}^{\rho_{\mathrm{c}}}+\beta_{\mathrm{r}, \mathrm{c}, \mathrm{ir}, \mathrm{w}} W_{\mathrm{r}, \mathrm{c}, \mathrm{ri}}^{\rho_{\mathrm{c}}}\right)^{\frac{\delta_{\mathrm{r}, \mathrm{c}, \mathrm{ir}}}{\rho_{\mathrm{c}}}} \\
Q_{\mathrm{r}, \mathrm{c}, \mathrm{rf}}=\alpha_{\mathrm{r}, \mathrm{c}, \mathrm{rf}} A_{\mathrm{r}, \mathrm{c}, \mathrm{rf}}^{\delta_{\mathrm{r}}}
\end{array}\right.
\end{aligned}
$$

The subscript "r" refers to the SRB and LRB; "c" refers to crop group (i.e. rice, wheat, maize, soybean, sugar crops, edible oil crops, cotton, vegetable and other crops); "ir" refers to irrigated production, and "rf" refers to rainfed production; the subscript "a" refers to the parameter related to land, and the subscript " $w$ " refers to the parameter related to irrigation water; "cc" refers to climate change scenarios (we used the average values from $26 \mathrm{cmip} 5 \mathrm{GCMs}$ under different representative concentration pathways (RCP), Ma et al., 2015); the reference information is indicated with bars.

The following are the definitions of the variables in the model systems:

- $A_{\mathrm{r}, \mathrm{c}, \text { ir }}$ and $A_{\mathrm{r}, \mathrm{c}, \mathrm{rf}}$ : choice variables in this model, representing sown areas of irrigated and rainfed crops by river basin, respectively;

- $W_{\mathrm{r}, \mathrm{c}, \mathrm{ir}}$ : a choice variable in this model, indicating the irrigation water use by crop and by river basin;
- $P_{\mathrm{r}, \mathrm{c}}$ : the crop commodity price by river basin;

- $Q_{\mathrm{r}, \mathrm{c}, \mathrm{ir}}$ and $Q_{\mathrm{r}, \mathrm{c}, \mathrm{rf}}$ : irrigated and rainfed crop production by crop and river basin, respectively;

- $C_{\mathrm{r}, \mathrm{c}, \mathrm{a}}$ : the observed cost of inputs other than irrigation water, including seeds, fertilizer, pesticide, etc.;

- $C_{\mathrm{r}, \mathrm{c}, \mathrm{w}}$ : the observed cost of the irrigation water used by crop by river basin;

- $\mu_{\mathrm{r}, \mathrm{c}, \mathrm{a}, \mathrm{ir}}$ and $\mu_{\mathrm{r}, \mathrm{c}, \mathrm{a}, \mathrm{rf}}$ : the shadow cost of irrigated and rainfed land, respectively;

- $\mu_{\mathrm{r}, \mathrm{c}, \mathrm{w}}$ : the shadow cost of irrigation water;

- $I_{\mathrm{cc}}$ : the available water supply for irrigation by river basin under climate change;

- $\alpha_{\mathrm{r}, \mathrm{c}, \text { ir }}$ and $\alpha_{\mathrm{r}, \mathrm{c}, \mathrm{rf}}$ : the scaling parameter of the production function, $\alpha>0$;

- $\beta_{\mathrm{r}, \mathrm{c}, \mathrm{ir}, \mathrm{a}}$ and $\beta_{\mathrm{r}, \mathrm{c}, \mathrm{ir}, \mathrm{w}}$ : the share parameters of production function, $\left(\beta_{\mathrm{r}, \mathrm{c}, \mathrm{ir}, \mathrm{a}}, \beta_{\mathrm{r}, \mathrm{c}, \mathrm{ir}, \mathrm{w}}\right) \in[0,1]$ and $\beta_{\mathrm{r}, \mathrm{c}, \mathrm{ir}, \mathrm{a}}+$ $\beta_{\mathrm{r}, \mathrm{c}, \mathrm{ir}, \mathrm{w}}=1$;

$-\delta_{\mathrm{r}, \mathrm{c}, \text { ir }}$ and $\delta_{\mathrm{r}, \mathrm{c}, \mathrm{rf}}$ : the return-to-scale parameters of irrigated and rain-fed production, $\delta_{\mathrm{r}, \mathrm{c}} \in(0,1)$;

- $\rho_{\mathrm{c}}$ : the substitution parameter, $\rho_{\mathrm{c}} \in(-\infty, 0) \cup(0,1)$.

In the above program, Eq. (1) is the objective function, which is to maximize the producer's profit $\Pi_{r}$ subject to the land constraint (2), water constraint (3). In the objective function (1), a crop's profit is defined as the difference between gross revenue and the cost of crop production. A crop's gross revenue is the product of its output and its selling price. The cost of crop production includes the costs of using irrigated land, rainfed land and irrigation water, each of which consists of two parts, the observed cost and the shadow cost. The observed cost of irrigated land and rainfed land include the cost of all types of input cost except irrigation water, such as seeds, pesticides, fertilizers and labor, the observed cost of irrigation water is the water fees. The land constraint (2) requires that the total area allocated to all crops not exceed the total land available in the base year. The water constraint (3) implies that the agricultural water use in each river basin cannot be more than the irrigation water supply under each climate change scenario. In the objective function, crop's total output changes with its sown area and irrigation water. Equation (4) is a production function for irrigated crop with a constant elasticity of substitution (CES) between irrigated land and irrigation water. When crop planted on rainfed land, no irrigation water is used, and the production function can be simplified as Eq. (5). 


\subsection{Estimation of Energy consumption and GHG emission}

The Energy consumption of and GHG emission from irrigation activities mainly depend on pumping, conveying and pressurizing water for application to the field (Rothausen and Conway, 2011). Due to data limit, we calculate emission from groundwater pumping for irrigation and then derive the emission from pumping surface water by using a conversion factor. According to the method introduced by Wang et al. (2012), the emission from pumping groundwater for irrigation can be calculated in the following steps.

First, the energy use rate is calculated by using

Energy use rate $\left(\mathrm{kWhm}^{-3}\right)=\frac{9.8 \mathrm{~m} \mathrm{~s}^{-2} \times \text { Lift }(\mathrm{m})}{3.6 \times 10^{3} \times \operatorname{Efficiency~}(\%)}$

which means that the energy required to lift $1 \mathrm{~m}^{3}$ of water $1 \mathrm{~m}$ up at $100 \%$ efficiency is $0.0027 \mathrm{kWh}$ (Rothausen and Conway, 2011). Lift, the most crucial factor in the energy use rate, relates to the vertical distance over which water is raised before its application to the field. The average pump lift for the SRB and LRB is from provincial data, and the estimated relationship based on groundwater level is in Wang et al. (2012) (see Table 7). Another key factor in Eq. (6) is pumping efficiency. In China, there are two types of pump engines, namely, electric and diesel; their shares are 76 and $24 \%$, respectively, and their pumping efficiency are set at $40 \%$ (with an additional $15 \%$ transmission and distribution loss) and $15 \%$, respectively, according to Wang et al. (2012).

Second, a conversion factor is used to derive the GHG emission rate from the energy use rate, which is $0.32021 \mathrm{kgCO}_{2} \mathrm{ekWh}^{-1}$ for diesel and $0.94773 \mathrm{~kg} \mathrm{CO}_{2} \mathrm{e} \mathrm{kWh}^{-1}$ for electricity produced in China (Wang et al., 2012). Equation (7) illustrates this calculation:

$$
\begin{aligned}
& \text { GHG emissionrate }\left(\mathrm{kg} \mathrm{CO}_{2} \mathrm{e} \mathrm{m}^{-3}\right)= \\
& \text { Energy use rate } \text { Electric }\left(\mathrm{kWh} \mathrm{m}^{-3}\right) \times \text { Share }_{\text {Electric }}(\%) \\
& \times 0.94773 \mathrm{~kg} \mathrm{CO}_{2} \mathrm{e} \mathrm{kWh}^{-1}
\end{aligned}
$$

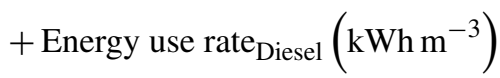

$$
\begin{aligned}
& \times \text { Share }_{\text {Diesel }}(\%) \times 0.32021 \mathrm{~kg} \mathrm{CO}_{2} \mathrm{e} \mathrm{kWh}^{-1} \text {, }
\end{aligned}
$$

Third, with the agricultural water use simulated by the CWSM model and the share of groundwater use (calculated based on proportion of groundwater-fed irrigated area from Wang et al. (2012) and the change rate of the groundwater supply from the CWSM model) under different scenarios, the groundwater pumped for irrigation can be derived. Then, the resulting energy consumption and GHG emission from groundwater irrigation can be calculated as the product of the energy use rate and GHG emission rate and groundwater use in agriculture.
The above steps are used to calculate the GHG emission from pumping groundwater for irrigation. For the total GHG emission from both surface water and groundwater pumping irrigation, a conversion coefficient of 0.58 is used. In China, the installed pumping capacity for surface water and groundwater are 22 million and 37.7 million $\mathrm{kW}$ respectively (Wang et al., 2012); thus, the ratio between emission from pumping surface water and groundwater is 0.58 . That is, the total emission from irrigation are 1.58 times the emission from groundwater pumping.

\subsection{Scenario specification}

To simulate the impact of climate change in the future, we set a reference scenario without climate change and two alternative climate change scenarios. The base year in our study is 2010 , represented by the average level of temperature and precipitation from 1990 to 2019, and the projection year is 2030, represented by the average level from 2020 to 2049 . Historical data are mainly calculated from the China Statistical Yearbook published by National Bureau of Statistics of China and China Water Resources Bulletin published by the Ministry of Water Resources and calibrated by using survey data from the CCAP (Chinese Center for Agricultural Policy, Peking University).

\subsubsection{Reference scenario}

There are three main water use sectors in the system, namely, the agricultural, industrial and domestic sectors. Without climate change, their water demands of water are determined by principally socioeconomic development and water use efficiency, with the total supply of water in 2030 remaining unchanged. For more details about the water balance in our model, see Wang et al. (2013).

In the agricultural sector, we assume that the sown area, cropping pattern and yield stay the same as in 2010. The development of agriculture is represented by the increase in irrigated areas. According to information in the National Integrated Water Resources Plan 2010-2030 from the Ministry of Water Resources (MWR) in China, irrigated areas in SRB and LRB will expand by 13 and $17 \%$, respectively. For the industrial sector, the annual growth rate of GDP in Northeast China will be $4.4 \%$ but with gradually declining growth rates from $5.1 \%$ in 2010-2020 to $3.8 \%$ in 2020-2030 (Sun et al., 2008). Regarding the domestic sector, the key factors are population and the urbanization rate. Population data are from the recent projection by the United Nations, which shows that the average annual population growth rate will be $0.34 \%$ in $2011-2030$, ranging from approximately $0.5 \%$ in 2011 to nearly zero in 2030 . As projected by IIASA, the urbanization rate in Northeast China will increase by approximately $22 \%$ from 2010 to 2030 (Toth et al., 2008).

To prevent the impact of climate change from being overwhelmed, we assume that the water use efficiency in various 
sectors (agricultural, industrial and domestic sectors) in 2030 will be equal to that in the base year of 2010 . Water use efficiency in the agricultural sector is measured by the share of crop water consumption over the total water withdrawal in the agricultural sector at the basin level. Industrial water use efficiency or the industrial water use quota is measured by water consumption per 10000 RMB Yuan of GDP in the industrial sector. Water use efficiency in the domestic sector has been divided into rural and urban areas, and it is measured by the per capita daily water use quota in rural and urban areas, respectively.

\subsubsection{Climate change scenarios}

Representative Concentration Pathways (RCPs) are used in this paper to provide future changes in climate variables, temperature and precipitation. Compared with the SRES scenarios (Nakicenovic et al., 2000), RCPs are a new set of climate scenarios, and they cover a wide range of year- 2100 global radiative forcing levels (from 2.6 to $8.5 \mathrm{~W} \mathrm{~m}^{-2}$ ) that were introduced in a special issue of Climatic Change in 2011 (Van Vuuren et al., 2011a).

RCP2.6 represents the lowest emission and radiative forcing. Under this scenario, the increase in the global mean temperature is limited to $2{ }^{\circ} \mathrm{C}$, and emission from energy use will be negative in the second half of the 21 st century. It requires the full participation of all nations, the rapid implantation of new technologies, and sufficient political and societal support (Van Vuuren et al., 2011b). Under RCP8.5, it is assumed that the population growth rate is high, the income growth rate is relatively low, technological change and energy intensity improvements are at modest rates, and climate mitigation policies are absent. As a result, RCP8.5 will have the highest greenhouse gas emission among all RCPs (Riahi et al., 2011).

To obtain high-resolution changes in temperature and precipitation in the SRB and LRB, 26 CMIP5 models are used (Ma et al., 2014). Given the temperature and precipitation under the two RCPs, the future changes in runoff are then estimated by using the CWSM. As shown in Table 1, both the average temperature and precipitation in Northeast China under the RCPs in 2030 will be higher than those in 2010 . The future average temperature will increase by up to $2.19^{\circ} \mathrm{C}$, and the change in precipitation will vary from 3.41 to $7.07 \%$ in the SRB and LRB. As a result, the runoff of Northeast China under the RCP scenarios will be 3.30 to $5.98 \%$ lower than it is in 2010. Clearly, the LRB will be affected more negatively by climate change than the SRB. Comparing all four RCP scenarios, RCP8.5 has the most negative effects on runoff (simulated by using climate elasticity, Fu et al., 2007) in both the SRB and the LRB, whereas RCP6.0 has the mildest effects. To capture a wide range of future climate change, RCP6.0 and RCP8.5 are used for further simulations.

Climate change will directly affect the crop yield and water balance. The direct impacts of climate change on the crop
Table 1. Change in the average annual temperature, precipitation and runoff under alternative climate change scenarios from 2010 to 2030 .

\begin{tabular}{|c|c|c|c|c|}
\hline & \multicolumn{4}{|c|}{ Climate Scenarios } \\
\hline & $\mathrm{RCP} 2.6$ & $\mathrm{RCP} 4.5$ & RCP6.0 & $\mathrm{RCP} 8.5$ \\
\hline \multicolumn{5}{|c|}{ Change in temperature $\left({ }^{\circ} \mathrm{C}\right)$} \\
\hline SRB & 1.8 & 1.71 & 1.82 & 2.19 \\
\hline LRB & 1.5 & 1.43 & 1.36 & 1.9 \\
\hline \multicolumn{5}{|c|}{ Change in precipitation $(\%)$} \\
\hline SRB & 5.58 & 5.34 & 7.07 & 5.59 \\
\hline LRB & 4.05 & 4.26 & 6.16 & 3.41 \\
\hline \multicolumn{5}{|c|}{ Change in runoff $(\%)$} \\
\hline SRB & -3.3 & -3.12 & -1.74 & -5.44 \\
\hline LRB & -4.21 & -3.83 & -0.55 & -5.98 \\
\hline
\end{tabular}

yield are not considered in our study because convincing estimations of the effects on the yield of many crops under the RCPs are not currently available (Ju et al., 2013). Thus, in this paper, we focus on the effects of climate change on crop production through its impacts on the water balance. As discussed above, the SRB and LRB under the two climate scenarios differ in temperature, precipitation and runoff, leading to different impacts on the water supply and water demand in 2030. According to the simulation of the CWSM (Table 2), compared with the reference scenario, the water supply in the SRB will drop by 1.44 to $4.49 \%$ under the RCPs, whereas the water supply in the LRB will drop by as much as $7.88 \%$ (under RCP8.5). Meanwhile, the water demand increases by approximately $1 \%$ mainly because of the increasing irrigation demand of crops. Consequently, climate change will further widen the gap between the water supply and the water demand. In the LRB under the RCP8.5, the water gap rate (share of water shortage in demand) will be almost $7 \%$ higher than the reference scenario in 2030.

\section{Results and Discussions}

\subsection{Agricultural production under climate change without optimization adjustments}

Suppose that farmers facing climate change will not optimize their production, which means that cropping patterns will remain exactly the same and irrigation water will be allocated to each crop according to its share of irrigation demand under the reference scenario. Thus, the percentage change of irrigated area, rainfed area and sown area will be zero and that of irrigation intensity equal the reduction ratio of irrigation supply. Since crops' total output and their yield, as well 
Table 2. Change in the water balance under alternative climate change scenarios compared with the reference scenario in 2030 (\%).

\begin{tabular}{lcccc}
\hline & \multicolumn{4}{c}{ Climate Scenarios } \\
\cline { 2 - 5 } & RCP2.6 & RCP4.5 & RCP6.0 & RCP8.5 \\
\hline Water supply & & & \\
\hline SRB & -2.73 & -2.58 & -1.44 & -4.49 \\
LRB & -5.55 & -5.05 & -0.73 & -7.88 \\
\hline Water demand & & & \\
\hline SRB & 0.81 & 0.44 & 0.39 & 1.34 \\
LRB & 0.39 & 0.11 & 0.02 & 1.68 \\
\hline Water gap rate & & & \\
\hline SRB & -2.54 & -2.19 & -1.36 & -4.11 \\
LRB & -4.36 & -3.82 & -0.76 & -6.79 \\
\hline
\end{tabular}

Sources: Simulation results based on the CWSM model.

as total profits and profit per ha, will vary to the same extent, we only show the results of the average crop yield in Table 3 and the total profits in Table 4.

In Northeast China, the average yield of all crops decreases under both two climate change scenarios. In both the SRB and the LRB, rice and wheat suffer the most negative impacts of climate change and vegetables will also experience a considerable yield loss. These crops have a relatively high water sensitivity under irrigation, which means that they will be more affected when the irrigation water supply decreases because of climate change. The total profits at the basin level also decline, but the profits of crops widely vary. Cotton and sugar crops will experience a huge increase in profits, whereas the other seven crops will face losses in the profit. RCP8.5 in the LRB has the most profound impact on agricultural production, especially for rice. All of these changes are highly in line with the fluctuation in the irrigation water supply.

Sources: Simulation results based on the CWSM model

Table 4 Percentage change in total profits under two climate scenarios without optimization in 2030 (compared with the reference scenario, \%)

Sources: Simulation results based on the CWSM model

\subsection{Adjustment of agricultural production to climate change}

Considering the adjustments made by farmers, the simulated effects of climate change on agricultural production under two climate change scenarios are presented in Tables 5 and 6 , including the cropping pattern, irrigation intensity, average crop yield (of both irrigated and rainfed crops), crop outputs and agricultural profits.
Table 3. Percent change in yield under two climate scenarios autonomous adaptation in 2030 (compared with the reference scenario, \%).

\begin{tabular}{lrr|rr}
\hline & \multicolumn{2}{c|}{ SRB } & \multicolumn{2}{c}{ LRB } \\
\cline { 2 - 5 } & RCP6.0 & RCP8.5 & RCP6.0 & RCP8.5 \\
\hline Rice & -1.14 & -3.67 & -0.41 & -5.55 \\
Wheat & -0.82 & -2.64 & -0.31 & -4.22 \\
Maize & -0.23 & -0.75 & -0.13 & -1.79 \\
Soybean & -0.10 & -0.34 & -0.05 & -0.64 \\
Sugar crops & -0.35 & -1.13 & -0.12 & -1.60 \\
Oil crops & -0.14 & -0.47 & -0.06 & -0.79 \\
Cotton & -0.25 & -0.83 & -0.08 & -1.11 \\
Vegetable & -0.69 & -2.24 & -0.17 & -2.39 \\
Other crops & -0.18 & -0.58 & -0.08 & -1.09 \\
\hline
\end{tabular}

Sources: Simulation results based on the CWSM model.

Table 4. Percentage change in total profits under two climate scenarios without optimization in 2030 (compared with the reference scenario, \%).

\begin{tabular}{lrr|rr}
\hline & \multicolumn{2}{c|}{ SRB } & \multicolumn{2}{c}{ LRB } \\
\cline { 2 - 5 } & RCP6.0 & RCP8.5 & RCP6.0 & RCP8.5 \\
\hline Total & -1.12 & -3.58 & -0.37 & -5.06 \\
Rice & -3.39 & -10.72 & -1.06 & -13.89 \\
Wheat & -1.56 & -4.98 & -0.57 & -7.62 \\
Maize & -0.61 & -1.98 & -0.27 & -3.73 \\
Soybean & -0.46 & -1.49 & -0.20 & -2.75 \\
Sugar crops & -0.98 & -3.15 & -0.33 & -4.52 \\
Oil crops & -0.50 & -1.60 & -0.23 & -3.12 \\
Cotton & -0.79 & -2.59 & -0.26 & -3.71 \\
Vegetable & -1.52 & -4.88 & -0.41 & -5.63 \\
\hline
\end{tabular}

Sources: Simulation results based on the CWSM model.

\subsubsection{Cropping pattern and irrigation intensity}

The reallocation of land and water within crops in the PMP model is realized by the adjustments of the cropping pattern and irrigation intensity. Theoretically, when water scarcity in Northeast China becomes more serious, the irrigated area of each river basin and crop, in addition to the irrigation water intensity, will decrease, and the rainfed area will increase. Because RCP8.5 represents the climate change scenario with the highest emission, we will focus on its impacts on agricultural production through water availability in the SRB and LRB below.

The shares of irrigated area to the total sown area in the SRB and LRB are 32.24 and $42.91 \%$, respectively, under the reference scenario and they fall to 31.86 and $42.59 \%$, respectively, under RCP8.5. Due to the relatively high sensitivity of the yield response to water and the relatively low gross revenues per hectare, the most striking effects of the decrease in the irrigated area will occur in rice, soybean and sugar crops, 
Table 5. Percent changes of key factors in the SRB River Basin under climate in $2030(\%)$.

\begin{tabular}{|c|c|c|c|c|}
\hline & $\begin{array}{r}\text { Sown } \\
\text { area }\end{array}$ & $\begin{array}{r}\text { Irrigated } \\
\text { area }\end{array}$ & $\begin{array}{r}\text { Rain-fed } \\
\text { area }\end{array}$ & $\begin{array}{l}\text { Irrigation } \\
\text { intensity }\end{array}$ \\
\hline \multicolumn{5}{|l|}{ RCP6.0 } \\
\hline Total & 0.00 & -0.36 & 0.17 & -0.57 \\
\hline Rice & -0.87 & -0.87 & 0.00 & -0.46 \\
\hline Wheat & -0.03 & -0.12 & 0.17 & -0.88 \\
\hline Maize & 0.19 & 0.45 & 0.12 & -0.53 \\
\hline Soybean & 0.09 & -0.90 & 0.25 & -0.41 \\
\hline Sugar crops & -0.25 & -0.92 & 0.10 & -0.71 \\
\hline Oil crops & 0.22 & -0.05 & 0.30 & -0.33 \\
\hline Cotton & -0.10 & -0.25 & 0.07 & -0.19 \\
\hline Vegetable & 0.06 & 0.07 & 0.02 & -0.11 \\
\hline Other crops & 0.08 & 0.10 & 0.08 & -0.32 \\
\hline \multicolumn{5}{|l|}{ RCP8.5 } \\
\hline Total & 0.00 & -1.17 & 0.56 & -7.59 \\
\hline Rice & -2.84 & -2.84 & 0.00 & -6.19 \\
\hline Wheat & -0.04 & -0.29 & 0.56 & -11.87 \\
\hline Maize & 0.62 & 1.48 & 0.38 & -7.23 \\
\hline Soybean & 0.28 & -2.91 & 0.79 & -5.47 \\
\hline Sugar crops & -0.78 & -2.93 & 0.33 & -9.50 \\
\hline Oil crops & 0.75 & 0.00 & 0.97 & -4.42 \\
\hline Cotton & -0.30 & -0.83 & 0.24 & -2.59 \\
\hline Vegetable & 0.18 & 0.20 & 0.07 & -1.53 \\
\hline \multirow[t]{2}{*}{ Other crops } & 0.26 & 0.30 & 0.25 & -4.38 \\
\hline & Output & Yield & $\begin{array}{r}\text { Total } \\
\text { Profits }\end{array}$ & $\begin{array}{l}\text { Profits } \\
\text { per ha }\end{array}$ \\
\hline \multicolumn{5}{|l|}{ RCP6.0 } \\
\hline Total & - & - & -0.95 & -0.95 \\
\hline Rice & -1.31 & -0.44 & -3.93 & -3.08 \\
\hline Wheat & -1.16 & -1.13 & -2.00 & -1.97 \\
\hline Maize & -0.09 & -0.28 & -0.41 & -0.60 \\
\hline Soybean & -0.05 & -0.14 & -0.40 & -0.49 \\
\hline Sugar crops & -0.53 & -0.29 & -1.17 & -0.93 \\
\hline Oil crops & -0.15 & -0.37 & -0.35 & -0.57 \\
\hline Cotton & -0.09 & 0.01 & -0.61 & -0.51 \\
\hline Vegetable & -0.08 & -0.14 & -0.61 & -0.67 \\
\hline Other crops & -0.07 & -0.15 & -0.63 & -0.71 \\
\hline \multicolumn{5}{|l|}{ RCP8.5 } \\
\hline Total & - & - & -3.02 & -3.02 \\
\hline Rice & -4.21 & -1.41 & -12.39 & -9.83 \\
\hline Wheat & -3.72 & -3.68 & -6.30 & -6.26 \\
\hline Maize & -0.28 & -0.90 & -1.33 & -1.94 \\
\hline Soybean & -0.17 & -0.44 & -1.30 & -1.57 \\
\hline Sugar crops & -1.70 & -0.93 & -3.75 & -2.99 \\
\hline Oil crops & -0.49 & -1.23 & -1.12 & -1.85 \\
\hline Cotton & -0.31 & -0.01 & -1.97 & -1.68 \\
\hline Vegetable & -0.26 & -0.44 & -1.96 & -2.14 \\
\hline Other crops & -0.23 & -0.48 & -2.05 & -2.30 \\
\hline
\end{tabular}

Sources: Simulation results based on the CWSM model. by approximately $2.9 \%$ in the SRB and $6.5 \%$ in the LRB. By contrast, maize and vegetables will experience an expansion in the irrigated area, in addition to wheat (by 1.48 and $1.92 \%$ in the SRB and the LRB, respectively).

The rainfed areas in both river basins will expand, by $0.56 \%$, with the growth rate crop varying from $0.07 \%$ (vegetable) to $0.97 \%$ (oil crops) in the SRB and $0.11 \%$ (vegetable) to $0.98 \%$ (soybean) in the LRB. Note that there are no rainfed rice in Northeast China under any scenarios due to insufficient rainfall.

Correspondingly, the sown area of each crop will change with the decrease in the irrigated area and the increase in the rainfed area. The crops that will expand and contract the most are maize and rice, respectively, in both the SRB (0.62 and $-2.84 \%$, respectively) and the LRB (1.13 and $-6.72 \%$, respectively). However, maize, soybean and rice will still be the dominant crops in Northeast China, and their shares of sown area to the entire basin's will hardly change, based on the calibration methods we used and the assumptions of stability in the sown area of the entire basin under all scenarios.

Under the reference scenario, the irrigation intensity in the SRB and LRB will be 3522 and $3650 \mathrm{~m}^{3} \mathrm{ha}^{-1}$, respectively. With the reduction in water availability under climate change scenario RCP8.5, the irrigation intensity in these two river basins will decrease by 4.07 and $7.59 \%$, respectively. The extent to which the irrigation intensity of crops will decrease depends on the water-yield response and gross revenue per hectare. For example, in the LRB, the irrigation intensities of oil crops will decline the most (by $8.41 \%$ ) as a consequence of being the least profitable crops.

\subsubsection{Crop outputs and yield}

Despite the considerable reduction in water availability under RCP8.5, the crop outputs of the SRB and LRB will not change significantly. Thanks to the adjustments in the cropping pattern and irrigation intensity, the resulted output are higher than those without adaptation measures. For example, the reduction of the output of grain crops (rice, wheat and maize) in the LRB declines from 2.35 to $2.16 \%$. Rice and wheat are the most water-sensitive crops; their output in the LRB drops the most (by approximately 8.5 and $7.2 \%$, respectively). In Northeast China, wheat production is marginal, but the promotion of rice should be considered carefully given the sharp drop in the water supply as a result of climate change.

Regarding the average crop yield, the only crop whose yield increases is cotton in the LRB, by $0.2 \%$. A large drop in the wheat production of the LRB will occur $(5.65 \%)$. Generally, crop yields does not change as much as those of irrigated area or water intensity in our model. The reason is partly related to the assumption that the production of crop is diminishing marginal return. However, the most important reason is, unlike many studies on the impact of climate change on yield (Wang et al., 2009; Tao and Zhang, 2010), we consider 
Table 6. Percent changes of key factors in the LRB under climate scenarios in $2030(\%)$.

\begin{tabular}{|c|c|c|c|c|}
\hline & $\begin{array}{r}\text { Sown } \\
\text { area }\end{array}$ & $\begin{array}{r}\text { Irrigated } \\
\text { area }\end{array}$ & $\begin{array}{r}\text { Rainfed } \\
\text { area }\end{array}$ & $\begin{array}{l}\text { Irrigation } \\
\text { intensity }\end{array}$ \\
\hline \multicolumn{5}{|l|}{ RCP6.0 } \\
\hline Total & 0.00 & -0.06 & 0.04 & -1.26 \\
\hline Rice & -0.49 & -0.49 & 0.00 & -0.99 \\
\hline Wheat & -0.14 & -0.20 & 0.06 & -2.21 \\
\hline Maize & 0.08 & 0.14 & 0.04 & -1.29 \\
\hline Soybean & -0.04 & -0.46 & 0.07 & -0.90 \\
\hline Sugar crops & -0.15 & -0.52 & 0.04 & -1.67 \\
\hline Oil crops & 0.00 & -0.19 & 0.05 & -2.64 \\
\hline Cotton & -0.07 & -0.16 & 0.04 & -0.29 \\
\hline Vegetable & 0.01 & 0.01 & 0.01 & -0.26 \\
\hline Other crops & 0.01 & -0.05 & 0.02 & -0.98 \\
\hline \multicolumn{5}{|l|}{ RCP8.5 } \\
\hline Total & 0.00 & -0.75 & 0.56 & -4.07 \\
\hline Rice & -6.72 & -6.72 & 0.00 & -3.18 \\
\hline Wheat & -1.64 & -2.49 & 0.87 & -7.14 \\
\hline Maize & 1.13 & 1.92 & 0.60 & -4.18 \\
\hline Soybean & -0.53 & -6.26 & 0.98 & -2.89 \\
\hline Sugar crops & -1.89 & -6.84 & 0.52 & -5.34 \\
\hline Oil crops & -0.10 & -2.69 & 0.63 & -8.41 \\
\hline Cotton & -0.97 & -2.26 & 0.52 & -0.94 \\
\hline Vegetable & 0.10 & 0.09 & 0.11 & -0.83 \\
\hline \multirow[t]{2}{*}{ Other crops } & 0.06 & -0.83 & 0.30 & -3.17 \\
\hline & Output & Yield & $\begin{array}{r}\text { Total } \\
\text { Profits }\end{array}$ & $\begin{array}{l}\text { Profits } \\
\text { per ha }\end{array}$ \\
\hline \multicolumn{5}{|l|}{ RCP6.0 } \\
\hline Total & - & - & -0.35 & -0.35 \\
\hline Rice & -0.63 & -0.14 & -1.68 & -1.19 \\
\hline Wheat & -0.54 & -0.40 & -0.95 & -0.81 \\
\hline Maize & -0.07 & -0.15 & -0.23 & -0.31 \\
\hline Soybean & -0.06 & -0.02 & -0.26 & -0.22 \\
\hline Sugar crops & -0.23 & -0.08 & -0.52 & -0.37 \\
\hline Oil crops & -0.04 & -0.03 & -0.23 & -0.22 \\
\hline Cotton & -0.05 & 0.01 & -0.29 & -0.22 \\
\hline Vegetable & -0.03 & -0.04 & -0.25 & -0.26 \\
\hline Other crops & -0.04 & -0.05 & -0.32 & -0.33 \\
\hline \multicolumn{5}{|l|}{ RCP8.5 } \\
\hline Total & - & - & -4.67 & -4.67 \\
\hline Rice & -8.49 & -1.90 & -21.42 & -15.76 \\
\hline Wheat & -7.20 & -5.65 & -12.16 & -10.70 \\
\hline Maize & -1.04 & -2.14 & -3.19 & -4.27 \\
\hline Soybean & -0.78 & -0.25 & -3.58 & -3.07 \\
\hline Sugar crops & -2.99 & -1.12 & -6.90 & -5.11 \\
\hline Oil crops & -0.51 & -0.41 & -3.11 & -3.01 \\
\hline Cotton & -0.78 & 0.20 & -3.98 & -3.04 \\
\hline Vegetable & -0.39 & -0.49 & -3.44 & -3.54 \\
\hline Other crops & -0.58 & -0.64 & -4.37 & -4.43 \\
\hline
\end{tabular}

Sources: Simulation results based on the CWSM model. only the indirect effect of climate change through the changing water stress and the effect of the optimization adjustment measures.

\subsubsection{Agricultural profits}

Agricultural profits decrease by 3.02 and $4.67 \%$ for the SRB and the LRB, respectively, under RCP8.5; these reductions are smaller than losses without optimization adjustment measures (3.58 and $5.06 \%$, respectively). This finding shows that farmers' autonomous adaptation measures such as adjusting the cropping pattern and irrigation intensity can effectively protect farmers' profits. Moreover, the profit loss at the basin level is much milder than the reduction in the irrigation water supply, in relative term. It can be understood in three ways. First, irrigated activities are not dominate in agricultural productions, only accounting for approximately $35 \%$ of the total sown area in Northeast China under the reference scenario, and will remain stable under climate change (as discussed above). Second, farmers can lower their irrigation water intensity, spending less on water fees and energy cost to adapt to declining water availability. Third, crop diversification at the basin level plays an important role in stabilizing agricultural profits. Although the total profits of producing a singlecrop drops by as much as $21.42 \%$ (rice in the LRB), such climate-related risks could be mitigated by planting a combination of diverse crops (for example, maize, oil crops and vegetables). Thus, confronting changing climatic conditions, farmers are recommended to diversify their crop portfolios (Huang et al., 2014).

\subsubsection{Sensitivity analysis}

The robustness of our model to the most important parameters, the substitution elasticity $\sigma$ and the supply elasticity $\eta$, are tested. The results show although the output and net profits are not sensitive to both parameters, the cropping pattern and irrigation intensity are directly related to them. For a better simulation, estimating the key parameters of the model by using survey data and econometric methods is highly recommended (Heckelei et al., 2012), as what we did in this study.

\subsection{Energy consumption and GHG emission}

As shown in Table 7, the groundwater level in the SRB and LRB is approximately $15 \mathrm{~m}$ below ground. According to the relationship between the pump lifts and the groundwater levels defined by Wang et al. (2012), the estimated pump lift is approximately $35 \mathrm{~m}$ in Northeast China. Using Eqs. (6) and (7), the energy use rate and GHG emission rate are estimated as $0.32 \mathrm{kWh} \mathrm{m}^{-3}$ and $0.25 \mathrm{~kg} \mathrm{CO}_{2} \mathrm{e} \mathrm{m}^{-3}$, respectively, in the SRB and $0.34 \mathrm{kWh} \mathrm{m}^{-3}$ and $0.27 \mathrm{~kg} \mathrm{CO}_{2} \mathrm{e} \mathrm{m}^{-3}$, respectively, in the LRB.

Under the reference scenario in 2030, the energy consumption in the SRB will be 4.91 million $\mathrm{kWh} \mathrm{m}^{-3}$ and 
Table 7. Energy use rate and GHG emission rate from irrigation in the SRB and LRB.

\begin{tabular}{lrr}
\hline & SRB & LRB \\
\hline Groundwater level $(\mathrm{m})$ & 13.82 & 16.43 \\
Estimated pump lift $(\mathrm{m})$ & 34.27 & 36.64 \\
Energy use rate $\left(\mathrm{kWh} \mathrm{m}^{-3}\right)$ & 0.32 & 0.34 \\
GHG emission rate $\left(\mathrm{kg} \mathrm{CO}_{2} \mathrm{e} \mathrm{m}^{-3}\right)$ & 0.25 & 0.27 \\
\hline
\end{tabular}

Sources: Calculated by the authors based on Wang et al. (2012).

that in the LRB is projected to be $50 \%$ less, 2.45 million $\mathrm{kWh} \mathrm{m}^{-3}$ (see Table 8). The total GHG emission from irrigation under the reference scenario will be 4.76 and $2.46 \mathrm{MtCO}_{2} \mathrm{e}$ in the SRB and LRB, respectively. Under the RCP scenarios, GHG emission are projected to decrease in both river basins, with change rate ranging from -2.36 to $-7.41 \%$ in the SRB and from -0.81 to $-10.07 \%$ in the LRB. This decrease is related to the reduction in the agricultural water supply as a result of climate change. If an increasing number of water-saving technologies, such as lowpressure pipelines, sprinklers and micro-irrigation, are used as planned by the government, the future trend of GHG emission from irrigation will be unclear because low-pressure pipelines are more energy consuming-efficient (Zou et al., 2013) whereas sprinklers and micro-irrigation are more energy consuming-intensive.

To have a general idea at the national level, the results of the other eight major river basins in China are calculated in the same manner. Under all four RCP scenarios, the total GHG emission from irrigation in China varies from $42.58 \mathrm{MtCO}_{2} \mathrm{e}$ (RCP8.5) to $45.12 \mathrm{MtCO}_{2} \mathrm{e}$ (RCP4.5), of which Northeast China accounts for approximately $16 \%$. If China is responsible for $20 \%$ of global GHG emission (IPCC, 2014), then the ratio of GHG emission from irrigation to total national emission will range from $0.4 \%$ (RCP8.5) to $0.75 \%$ (RCP2.6) in 2030. This ratio is calculated to be $0.58 \%$ in 2006 (Wang et al., 2012), and it will be higher under both the RCP2.6 and the RCP6.0 (0.62\%) scenarios. The significance of irrigation as a source of GHG emission should not be ignored but instead should draw more attention from both researchers and political leaders in China.

\section{Conclusion and policy implications}

The nexus among water, food, energy and GHG under climate change has become a hot topic in recent years. However, few integrated analysis of their relationships have been done so far. The purpose of this paper is to examine the nexus by assessing the effects of climate change on agricultural production through the change in water, evaluating the adjustment responses and the resulting energy consumption and GHG emission. The study area focuses on Northeast China,
Table 8. Total GHG emission from irrigation in the SRB and LRB in 2030 .

\begin{tabular}{|c|c|c|c|}
\hline & Reference & RCP6.0 & RCP8.5 \\
\hline \multicolumn{4}{|l|}{ SRB } \\
\hline $\begin{array}{l}\text { Agricultural water use } \\
\text { (billion } \mathrm{m}^{3} \mathrm{yr}^{-1} \text { ) }\end{array}$ & 23.30 & 22.95 & 22.19 \\
\hline Share of GW use ${ }^{b}(\%)$ & 51.16 & 50.71 & 49.75 \\
\hline $\begin{array}{l}\text { Agricultural GW use } \\
\text { (billion } \mathrm{m}^{3} \mathrm{yr}^{-1} \text { ) }\end{array}$ & 11.92 & 11.64 & 11.04 \\
\hline $\begin{array}{l}\text { Energy consumption } \\
\text { from GW pumping } \\
\left(\text { million } \mathrm{kWh} \mathrm{m}^{-3}\right)\end{array}$ & 3.78 & 3.69 & 3.5 \\
\hline $\begin{array}{l}\text { GHG emission from } \mathrm{GW} \\
\left(\mathrm{MtCO}_{2} \mathrm{e}\right)\end{array}$ & 3.01 & 2.94 & 2.79 \\
\hline $\begin{array}{l}\text { Total GHG emission }{ }^{\mathrm{c}} \\
\left(\mathrm{Mt} \mathrm{CO}_{2} \mathrm{e}\right)\end{array}$ & 4.76 & 4.65 & 4.41 \\
\hline \multicolumn{4}{|l|}{ LRB } \\
\hline $\begin{array}{l}\text { Agricultural water use } \\
\text { (billion } \mathrm{m}^{3} \mathrm{yr}^{-1} \text { ) }\end{array}$ & 11.96 & 11.89 & 11.05 \\
\hline Share of GW use ${ }^{\mathrm{b}}(\%)$ & 48.19 & 48.07 & 46.88 \\
\hline $\begin{array}{l}\text { Agricultural GW use } \\
\text { (billion } \mathrm{m}^{3} \mathrm{yr}^{-1} \text { ) }\end{array}$ & 5.76 & 5.71 & 5.18 \\
\hline $\begin{array}{l}\text { Energy consumption } \\
\text { from GW pumping } \\
\left(\text { million } \mathrm{kWh} \mathrm{m}^{-3}\right)\end{array}$ & 1.95 & 1.94 & 1.76 \\
\hline $\begin{array}{l}\text { GHG emission from } \mathrm{GW} \\
\left(\mathrm{MtCO}_{2} \mathrm{e}\right)\end{array}$ & 1.56 & 1.54 & 1.40 \\
\hline $\begin{array}{l}\text { Total GHG emission }{ }^{\mathrm{c}} \\
\left(\mathrm{MtCO}_{2} \mathrm{e}\right)\end{array}$ & 2.46 & 2.44 & 2.21 \\
\hline
\end{tabular}

which is a major grain production region and highly dependent on irrigation with a limited water endowment.

Based on our simulation results, by 2030, climate change will result in an increase in the water supply and demand gap for irrigation from 1.36 to $4.11 \%$ in the SRB and from 0.76 to $6.79 \%$ in the LRB in Northeast China under two climate scenarios, RCP6.0 and RCP8.5. Due to the increase in water scarcity, under the same climate scenarios, the irrigated areas in these two river basins decrease from 0.36 to $1.17 \%$ and from 0.06 to $0.75 \%$, respectively. In addition to the change in irrigated areas, the cropping pattern will be adjusted by farmers. The major adjustment in these two river basins is the increase in the maize sown areas and the decrease in the rice sown areas. As a result, the total output of crops will decline. For example, in the SRB, major grain production (wheat, maize and rice) will be reduced by from 1.26 to $1.47 \%$, while in the LRB, major grain production will be reduced by from 2.16 to $2.35 \%$. Further analysis also indicates a reduction in agricultural production profits by from 0.95 to $3.02 \%$ in the SRB and from 0.35 to $4.67 \%$ in the LRB. Finally, we find that, under RCP6.0 and RCP8.5, energy consumption and GHG emission will decrease by from 
2.36 to $7.41 \%$ in the SRB and from 0.81 to $10.07 \%$ in the LRB.

Our results have policy implications. First, in assessing the impacts of climate change, the nexus among water, food, energy and GHG emission should be fully considered; otherwise, the overall impacts of climate change will be underestimated. In addition, further research at the regional level in China is needed, especially for those regions that are expected to experience more serious water shortage under climate change, such as the Haihe, Huaihe and Yellow RBs.

Second, we found that the adaptation measures adopted by farmers will reduce the risk of climate change for agricultural production, which is a good news for China's food security. To mitigate the negative effects of climate change on agricultural production, implementing irrigation measures (such as extending water-saving technologies), optimizing the cropping pattern (reducing the sown area of water-intensive crops) and improving water productivities (such as planting drought-resilient varieties) are highly recommended.

Finally, energy consumption and GHG emission both decrease due to the reduction in irrigation water caused by climate change. That is, although climate change negatively influences water and agricultural production, it will not lead to a further increase in energy consumption and GHG emission. However, the estimation of energy consumption and GHG emission in this paper is mainly based on the change in the irrigation water supply. There are other factors that may affect future emission, such as the application of water-saving technologies, the limitations of pumping groundwater and the use of renewable energy sources for irrigation. How these factors influence energy consumption and GHG emission is an interesting topic for future research.

Data availability. The original data set can be accessed: http://www.mwr.gov.cn/english/publs/ and http://data.stats.gov. cn/english/easyquery.htm (last access: 13 April 2018).

Competing interests. The authors declare that they have no conflict of interest.

Special issue statement. This article is part of the special issue "Innovative water resources management - understanding and balancing interactions between humankind and nature". It is a result of the 8th International Water Resources Management Conference of ICWRS, Beijing, China, 13-15 June 2018.

Acknowledgements. We acknowledge financial support from the National Natural Sciences Foundation in China (71161140351).

Edited by: Zongxue Xu

Reviewed by: two anonymous referees

\section{References}

Bazilian, M., Rogner, H., Howells, M., Hermann, S., Arent, D., Gielen, D., Steduto, P., Mueller, A., Komor, P., Tol, R. S. J., and Yumkella, K. K.: Considering the energy, water and food nexus: Towards an integrated modelling approach, Energ. Policy, 39, 7896-7906, 2011.

Cobuloglu, H. I. and Büyüktahtakın, İ. E.: Food vs. biofuel: An optimization approach to the spatio-temporal analysis of land-use competition and environmental impacts, Appl. Energ., 140, 418434, 2015.

ECSNCCA (Edition Committee of the Second National Climate Change Assessment): Second National Climate Change Assessment Report, Science Press, 2011.

Finley, J. W. and Seiber, J. N.: The nexus of food, energy, and water, J. Agr. Food Chem., 62, 6255-6262, 2014.

Fu, G., Charles, S. P., and Chiew, F. H. S.: A two-parameter climate elasticity of streamflow index to assess climate change effects on 80 annual streamflow, Water Resour. Res., 43, W11419, https://doi.org/10.1029/2007WR005890, 2007.

Graveline, N. and Mérel, P.: Intensive and extensive margin adjustments to water scarcity in France's Cereal Belt, European Review of Agricultural Economics, 41, 707-743, https://doi.org/10.1093/erae/jbt039, 2014.

Heckelei, T., Britz, W., and Zhang, Y.: Positive Mathematical Programming Approaches-Recent Developments in Literature and Applied Modelling, Bio-based and Applied Economics, 1, 109124, 2012.

Huang, J., Jiang, J., Wang, J., and Hou, L.: Crop Diversification in Coping with Extreme Weather Events in China, J. Integr Agr, 13, 677-686, 2014.

IPCC: Climate Change 2013: The Physical Science Basis, Contribution of Working Group I to the Fifth Assessment Report of the Intergovernmental Panel on Climate Change, Cambridge University Press, 1395-1445, 2014.

Ju, H., Lin, E., Wheeler, T., Challinor, A., and Jiang, S.: Climate Change Modelling and Its Roles to Chinese Crops Yield, J. Integr Agr, 12, 892-902, 2013.

Kao, S., Sale, M. J., Ashfaq, M., Uria Martinez, R., Kaiser, D. P., Wei, Y., and Diffenbaugh, N. S.: Projecting changes in annual hydropower generation using regional runoff data: An assessment of the United States federal hydropower plants, Energy, 80, 239250, 2015.

Keairns, D. L., Darton, R. C., and Irabien, A.: The Energy-WaterFood Nexus, Annual Review of Chemical \& Biomolecular Engineering, 7, 239, 2016.

Ma, J., Dong, W., Wei, Z., and Yan, X.: Evaluating daily surface maximum temperature interpolation error by adding climate stations near border areas over China, Int. J. Climatol., 35, 27982808, 2015.

Martin-Gorriz, B., Soto-García, M., and Martínez-Alvarez, V.: Energy and greenhouse-gas emissions in irrigated agriculture of SE (southeast) Spain. Effects of alternative water supply scenarios, Energy, 77, 478-488, 2014.

Mendelsohn, R. and Dinar, A.: Climate Change and Agriculture: An Economic Analysis of Global Impacts, Adaptation, and Distributional Effects, Edward Elgar Publishing, 2009.

Nakicenovic, N., Alcamo, J., Davis, G., De Vries, B., Fenhann, J., Gaffin, S., Gregory, K., Grubler, A., Jung, T. Y., Kram, T., 
La Rovere, E. L., Michaelis, L., Mori, S., Morita, T., Pepper, W., Pitcher, H. M., Price, L., Riahi, K., Roehrl, A., Rogner, H., Sankovski, A., Schlesinger, M., Shukla, P., Smith, S.J., Swart, R., Van Rooijen, S., Victor, N., and Dadi, Z.: Special Report on Emissions Scenarios: a special report of Working Group III of the Intergovernmental Panel on Climate Change, Cambridge University Press, 2000.

NBSC (National Bureau of Statistics of China): China statistical yearbook 2013, China Statistics Press, 2013.

Nelson, G. C., Robertson, R., Msangi, S., Zhu, T. J., Liao, X. L., and Jawajar, P.: Greenhouse gas mitigation: Issues for Indian agriculture, International Food Policy Research Institute, Environment and Production Technology Division, Washington, DC, IFPRI Discussion Papers 00900, 2009.

Rasul, G. and Sharma, B.: The nexus approach to water-energy-food security: an option for adaptation to climate change, Climate Policy, 16, 682-702, 2015.

Riahi, K., Rao, S., Krey, V., Cho, C., Chirkov, V., Fischer, G., Kindermann, G., Nakicenovic, N., and Rafaj, P.: RCP 8.5 - A scenario of comparatively high greenhouse gas emissions, Climatic Change, 109, 33-57, 2011.

Rosenzweig, C., Strzepek, K. M., Major, D. C., Iglesias, A., Yates, D. N., McCluskey, A., and Hillel, D.: Water resources for agriculture in a changing climate: international case studies, Global Environ. Change, 14, 345-360, 2004.

Rothausen, S. G. S. A. and Conway, D.: Greenhouse-gas emissions from energy use in the water sector, Nat. Clim. Change, 1, 210 219, 2011

Sun, L., Veen, W. V., Zhang, X., Huang, J., and Qiu, H.: China's Economic Growth outside the Farm Sector: Plausible Trends towards 2030, CATSEI Working Paper, available at: http://www.catsei.org/upload/2009/320093512113891. pdf (last access: 13 April 2018), 2008.

Tao, F. and Zhang, Z.: Adaptation of maize production to climate change in North China Plain: Quantify the relative contributions of adaptation options, Eur. J. Agron., 33, 103-116, 2010.

Toth, F. L., Cao, G., and Hizsnyik, E.: Regional population projections for China, International Institute for Applied Systems Analysis, Laxenburg, Austria, Interim Report IR-03-042, 1-55, 2008.
Van Vuuren, D. P., Edmonds, J. A., Kainuma, M., Riahi, K., and Weyant, J.: A special issue on the RCPs, Climatic Change, 109, 1-4, 2011a.

Van Vuuren, D. P., Stehfest, E., Den Elzen, M. G. J., Kram, T., Van Vliet, J., Deetman, S., Isaac, M., Klein Goldewijk, K., Hof, A., Mendoza Beltran, A., Oostenrijk, R., and van Ruijven, B.: RCP2.6: exploring the possibility to keep global mean temperature increase below $2{ }^{\circ} \mathrm{C}$, Climatic Change, 109, 95-116, $2011 \mathrm{~b}$.

Wang, J., Mendelsohn, R., Dinar, A., Huang, J., Rozelle, S., and Zhang, L.: The impact of climate change on China's agriculture, Agr. Econ.-Blackwell, 40, 323-337, 2009.

Wang, J., Rothausen, S. G. S. A., Conway, D., Zhang, L., Xiong, W., Holman, I. P., and Li, Y.: China's wate-energy nexus: greenhouse-gas emissions from groundwater use for agriculture, Environ. Res. Lett., 7, 014035, https://doi.org/10.1088/17489326/7/1/014035, 2012.

Wang, J., Huang, J., and Yan, T.: Impacts of climate change on water and agricultural production in ten large river basins in China, J. Integr. Agr., 12, 1267-1278, 2013.

Waughray, D.: Water security: the water-food-energy-climate nexus, World Economic Forum water initiative, island press, Washington, 2011.

Wise, M., Dooley, J., Luckow, P., Calvin, K., and Kyle, P.: Agriculture, land use, energy and carbon emission impacts of global biofuel mandates to mid-century, Appl. Energ., 114, 763-773, 2014.

Yan, T.: Optimal Allocation of Agricultural Water Use and Its Impacts on Crop Production under Climate Change: Study in Five Large River Basins in Northern China, The University of Chinese Academy of Sciences, 2015.

Zou, X., Li, Y., Cremades, R., Gao, Q., Wan, Y., and Qin, X.: Cost-effectiveness analysis of water-saving irrigation technologies based on climate change response: A case study of China, Agr. Water Manage., 129, 9-20, 2013. 